\title{
The Implementation of Scaffolding Strategies at Speaking English Course in Kampung Inggris Pare East Java
}

\author{
Diniyati Kesuma Sari ${ }^{1, *}$ Yenni Rozimela ${ }^{1}$ \\ ${ }^{1}$ Universitas Negeri Padang, Padang, Indonesia, \\ *Corresponding Author. Email: (e-mail) diniykesumas@gmail.com
}

\begin{abstract}
In particular, the teacher plays essential roles in assisting the learners to achieve the goals of learning. To improve the learners' capacity to the higher level maximally, the appropriate scaffolding strategy is needed. This study aimed to describe the implementation of scaffolding strategy used by teachers at Speaking English Course at Kampung Inggris Pare, East Java. This place is one of the biggest non-native English environment in Indonesia that provides an alternative way to improve learners' speaking ability outside formal education. This study was descriptive qualitative research using observation, interview, and documentary. The participants were two speaking teachers that were elected by purposive sampling. It was found that the scaffolding strategies that used by the teachers were set and share the goal of the study, offering an explanation, providing hint, modelling, verifying and clarifying learners' understanding, inviting the learners' participation, reformulation, verbal prompt, giving feedback, and drillings. These are some stimulations for the learners to be independent.
\end{abstract}

Keywords: Scaffolding strategy, teaching speaking, English course

\section{INTRODUCTION}

English is a foreign language in Indonesia that is only certain people who can communicate in English well. This condition makes students do not have interlocutor to practice speaking as mentioned by Fisher [8] that a good environment also allows people speaking to take more ownership of their ideas. When students study at an English course that is their own choice to take all the rules to be followed, it helps them easy to find friends that have the same aspiration with them. Biswas [5] mentioned that learning a language in a group work affect gain the physical and mental aspects to be more natural. Also, some of them claimed that learning English at school is not enough. Many students join the English course to gain language ability.

The benefit of English course as non-formal education is to expand and to give more drillings for students to master the language with various programs and flexible times. Some students need alternative treatment instead of studying the language at school. It is supported by Barkelle [4], he mentioned that English is a complicated subject to learn at school, some of the students get tired and bored in learning English. They need to enhance and maximize the achievement of English skill in other places like English course. The existence of an English course is for supplementary education for formal school in which to increase the ability of students to communicate in English. As many students which graduate from high school or up to university are still not capable to communicate in English properly, some of them claim that studying English at school for many years is not enough to communicate in English. Therefore, they decided to find another solution by joining English course to improve their ability.

According to Handoyo [13], in early 2010, an English community at Pare, Kediri, East Java, as well known as Kampung Inggris is becoming popular. Many students take several times to study English in this place. The strong point why this place is one of the highest options to study English in the English environment. Kampung Inggris Pare Kediri in East Java is one of non-formal education which provides many English courses with various programs and duration of the study. This place is also considered a big environment of non-formal education particularly for English course in Indonesia since more than 100 English courses registered.

A capture of the teaching process in Kampung Inggris might give a different atmosphere compared with other places such as schools or English course outside this area. A creative teaching process should guide students to make new interpretations about information or lessons by giving many chances for students to get involved in some experiments to have experienced. This process engages students to know what is learning or the focus is not the lesson but the process. Therefore, the teacher needs to think about what is appropriate teaching strategy based on student needs. One of the teaching methods that help students learn more by working with a teacher or a more advanced student to achieve their learning goals is well known as the scaffolding strategy. Scaffolding is the gradual reduction of support and guidance in response to a student's progressive competence in doing a task. This study is aimed to investigate the implementation of 
scaffolding strategy by teachers in teaching speaking at English Courses, Pare, East Java.

\subsection{Scaffolding}

Scaffolding is perceived as the strategy used by the teachers to facilitate learners' transition from assisted to independent performance (Vygotsky, [18]). According to Bruner and Wood in Gibbons [10], in literally used, scaffolding is a term that is usually used for something placed around the building. It is used as a temporary structure in the process of constructing a building. In other words, before as soon as the building can support itself, the scaffold is removed.

Scaffolding theory was first introduced in the late 1950s by Jerome Bruner, a cognitive psychologist. While the scaffolding instruction as a teaching strategy firstly developed by Lev Vygotsky. His research explains about sociocultural theory and a concept of the zone of proximal development (ZDP). Chen [6] describes that Vygotsky hypothesis about guided interactions with an adult could assist children to develop to a higher level of language. The zone of ZDP is the distance between the actual development as what children can do by themselves and the level of potential development which determined by teachers control or collaboration to solve many problems in language learning. The scaffolding process involves the development of cognitive and metacognitive aspects that is maybe guided by teachers as social and linguistic interaction.

In early research, they found that how parents help their children to interact with oral production. It was strongly helpful to make children do something beyond their independent effort. For example, intuitively, parents suddenly assist their children to negotiate among other children. This attempt would be practice step by step until the message clear to be transferred and them to be confirmed by the listeners. In the future, these children will get used to how to negotiate. Based on the nature of scaffolding, many teachers used the concept of ZDP in a variety of ways in education today. They believe that more focus on collaboration and social interaction in learning and teaching could give positive impacts. (Walqui, [14]). Hammond [12] and Gibbons [10] mentions that scaffolding has three main functions. They are to build student's knowledge, to give temporary support, and to specify micro and macro skills. They also explain the types of scaffolding used to influence the learning result. When students get a lower-level task and less scaffolding, the learning potential is also slow. Then, when students get a lower-level task with much scaffolding, the teacher will dominate the learning process. Lastly, when the students get a high-level task with less scaffolding, it makes students get frustrated. Consequently, the teachers should choose the correct ones to success the learning process, not only look at what students are capable of doing on their own, but also look at what they are capable of doing in a social setting.

\subsection{The Implementation of Scaffolding in Teaching Speaking}

The main goal of scaffolding strategy in teaching is to help students to be independent in completing tasks. Another necessary thing that should be concerned is the effectiveness of scaffolding strategy used by teachers. Vygotsky in Byrnes [3] suggests three characteristics. First, teachers need to be much aware not to be dominating for assistance within a long time, at the consideration to make students can work on their own. Based on the first step of scaffolding, he reminds for only giving some clues to lead the students to think and to do the work creatively. On the other words, teachers may give hints as initial performance when a student gets off track, then let them complete it all. Second, the instruction-level should always be within the zone of proximal development but still challenge them to enhance their knowledge. That is the way to minimalized under pressure. Lastly, teachers must keep on scientific concepts in teaching to avoid them from falling back to their earthy conceptions of the knowledge. Vygotsky who promotes cognitive development identifies four instructional scaffolding (Byrnes, [3]), they are (1) Modelling, in this first phase, teachers start with stimulating students to think and to feel the situation of what the outcome of learning looks like. They are guided to predict what they should do within the process. There are, at least, three strategies that can be implemented in this stage, think aloud, talk aloud and performance modelling. In this stage, the teacher must offer explanations explicitly about what is being learned (declarative or propositional knowledge), why and when it is used (conditional or situational), and how to use it (procedural knowledge). (2) Imitating, students try to copy what they get from the first stage. On the other words, the students begin guided practice by performing parts of the task that work in collaboration with the teachers and other students. Within the process of learning in this stage, the teacher assists the learners by giving assessment and feedback. (3) Removing, it is the time for the teacher begins to remove the scaffolding. Teachers give more chances for students to practice alone. It is still possible to have extensive instructional. (4) Achieving, students can produce the skill independently.

In teaching speaking as a skill which needs time and more effort to practice, teaching strategy plays an important role to achieve successful learning. Some strategies could be adjusted to the needs of the teaching process. In general, the main purpose of scaffolding is to build students' confidence in learning new information, since the teacher still assists them until they can complete the tasks independently. Scaffolding maintains the atmosphere of teaching and learning process. The teacher may have big opportunities to give feedback to students. It is a kind of mutual interaction between teacher and student that student is also allowed to confirm anything and anytime. Hence, the empowering of students' skill is possible to reach. (Abbas, [1]. 


\section{METHOD}

A descriptive qualitative study was conducted to investigate the implementation and the effectiveness of scaffolding strategy in teaching speaking in English courses at Pare, East Java. Heigham [15] explains that the focus of this study is to find out the general understanding of a phenomenon based on its context. The population and the data gathered from the natural setting which needs further investigation by doing some methods such as observation or interview (Gay, [11]). In this study, those methods were applied to see the way teacher scaffold their students in teaching speaking at English courses with the population were two English speaking courses. Mostly, these courses promote their purpose of teaching is to help students to increase their speaking ability. Furthermore, there were four English teachers are observed and interviewed to make a general conclusion about the real situation in teaching speaking. Those teachers have experienced in teaching English courses at least more than five years. Thus, they are mature enough to contribute to this research.

The observation was done in two days of one period which has ten days as standard learning duration in this place). Every meeting took 90 minutes. Some video recordings and pictures were taken through the observation. The researchers also noted some possible moments while teaching process based on a rubric specifically designed based on the indicators of scaffolding strategy as stated by Vygotsky. The indicators are modelling (think aloud, talk aloud, performance examples), imitating (copy what the students' get from the first stage), removing (having time to get practice), achieving (produce the task independently). To have more representative data, structures interview were formulated by using indicators of the implementation of scaffolding strategy in teaching speaking. Finally, in interpreting the data, a scale of the most frequent results was analyzed.

\section{RESULT AND DISCUSSION}

The implementation of a scaffolding strategy in teaching speaking is related to the purpose of the class. The aims of the two English courses are the same as the observation

Table 1. The summary of the implementation of scaffolding strategy in teaching some topics: listening session, telling story and debate. ware conducted by the researcher at an intermediate level. The topics learned were listening session, telling story and debate.

\subsection{The stages of scaffolding strategy in teaching speaking at English course, Kampung Inggris Pare}

The scaffolding strategy is anything used to help students to master a new skill or knowledge. It can be learning activity in the classroom, teaching methods, or media to support teaching process. The scaffolding stages may be integrated with suitable strategies that the teachers should choose based on the needs of the students. Lange [16] and Walqui [17] explains some significant pedagogical aspects in providing scaffolding: (1) Continuity, tasks are connected and sometimes need repetition. (2) Contextual support, build supportive environments to reach the goals in a variety of ways. (3) Intersubjectivity: supporting each other in mutual understanding among teachers and students and nonthreatening participation in practice. (4) Contingency, task and instruction given are adjusted based on the needs of the learners. (5) A takeover, when the task is increasing, the teachers may also take over parts of the action. On the other words, teachers are always careful of students. (6) Flow, skills and challenges should be in balance. Those are what is expected in implementing scaffolding in teaching.

Based on the observation and interview to the teachers. It was obvious that the most important point in implementing correct scaffolding strategy was knowing the level of the students. It helped teacher to set and share the goal of the study that should be balance with the challenges given to the students. As the result, in the first stage of scaffolding, there were many repetitions, collaborations, and drillings. These stimulated the students to get use to the focus of the languages. All scaffolding strategies were gradually removed over times as the challenges of the task was increased.

Based on the observation on the teaching and learning process at intermediate class -Kampung Inggris Pareteachers' activities in implementing scaffolding strategy in teaching speaking can be summarized in table below.

\begin{tabular}{|c|c|c|c|}
\hline \multirow{2}{*}{ Stage } & \multicolumn{3}{|c|}{ Scaffolding Strategy in Each Topic } \\
\hline & Listening session & Telling story & Debate \\
\hline I & $\begin{array}{l}\text { - Preparing the students to get } \\
\text { into the topic } \\
\text { - Sharing a song that related } \\
\text { to the lesson } \\
\text { - Reviewing vocabulary and } \\
\text { grammar based on the song }\end{array}$ & $\begin{array}{l}\text { - Preparing the students to get } \\
\text { into the topic } \\
\text { - Sharing some strategies to tell a } \\
\text { story } \\
\text { - Asking three students to } \\
\text { practice chain story with the } \\
\text { teacher } \\
\text { - Review vocabulary and } \\
\text { grammar }\end{array}$ & $\begin{array}{l}\text { Preparing the students to get into the topic } \\
\text { Giving some examples of telling opinion and } \\
\text { refuse opinion } \\
\text { Reviewing vocabulary and grammar }\end{array}$ \\
\hline II & $\begin{array}{l}\text { - Drilling the students to } \\
\text { - Giving opportunity for the } \\
\text { students to listen a podcast }\end{array}$ & $\begin{array}{l}\text { - Watching a short movie } \\
\text { - Giving further explanation }\end{array}$ & $\begin{array}{l}\text { Giving opportunity for the students to prepare } \\
\text { some ideas by having practice in their own group } \\
\text { (pro and cons) }\end{array}$ \\
\hline
\end{tabular}




\begin{tabular}{|c|c|c|c|}
\hline & $\begin{array}{l}\text { - Reviewing vocabulary and } \\
\text { grammar based on the } \\
\text { podcast }\end{array}$ & & Giving clarification and confirmation \\
\hline III & $\begin{array}{l}\text { - Giving opportunity for the } \\
\text { students to have speaking } \\
\text { practice based on the } \\
\text { podcast } \\
\text { - Giving time for clarification, } \\
\text { confirmation or discussion }\end{array}$ & $\begin{array}{l}\text { - Asking the students to make } \\
\text { their own story ending based on } \\
\text { the movie } \\
\text { - Giving opportunity for the } \\
\text { students to practice telling a } \\
\text { story in group } \\
\text { - Giving time for clarification, } \\
\text { confirmation or discussion }\end{array}$ & $\begin{array}{l}\text { Giving opportunity for the students to practice } \\
\text { debate in pairs } \\
\text { Giving time for clarification, confirmation or } \\
\text { discussion }\end{array}$ \\
\hline IV & $\begin{array}{l}\text { - Giving opportunity for the } \\
\text { students to answer a table } \\
\text { topic related to the podcast } \\
\text { - Giving feedback }\end{array}$ & $\begin{array}{l}\text { - Giving opportunity for the } \\
\text { students to tell a story in group } \\
\text { - Giving feedback }\end{array}$ & $\begin{array}{l}\text { Giving opportunity for the class to perform } \\
\text { debate in two groups (pro and cons) } \\
\text { Giving feedback }\end{array}$ \\
\hline
\end{tabular}

\section{Note:}

Stage of scaffolding: I) Modelling; II) Imitating; III) Removing; IV) Achieving

From the table above it can be seen that the teachers gradually removed the scaffolding strategy. They gave more chances for the students to have collaboration learning with the other students or with the teachers themselves. The teachers also invited each student to get involved in the process of learning such as speaking, listening and questioning related to the lesson. Therefore, all students got to participate in every classroom activity created by the teachers. Besides, the teachers also gave time for the students to discuss something that they were still in doubt by giving confirmation and clarification. In general, there was no significant difference among the teachers in the implementation of scaffolding strategy even though each teacher emphasized a specific strategy due to the needs' of the students.

Providing opportunities for learners to talk could be designed in many classroom activities and they could work by using group work or pair work. Groups encourage teamwork and help students get feedback from each process of developing the presentation. In classroom activities, the teachers in the English course were free to adjust many kinds of activity that suit to the goals of the learning. There were some classroom activities found on the observation such as discussion, role-play, debate, playing game or presentation. In every activity, the teachers gave more time for the students to have practice and limit teachers' talk. They only talked in some parts such as offering clarifications or sharing further explanation. It was a highlight that the teachers tried to encourage the students to speak and to get participated in every kind of classroom activity.

Furthermore, based on the interview to the teachers, the condition of the intermediate class was identified. The learners in this class were able to speak in English at 50\%. It assumes that they can use simple sentences, they have enough daily common vocabulary, they can produce correct pronunciation, they have already understood general contexts of life and they speak with frequent hesitation. Also, this class aimed to help the students to speak fluently, to build their self-confidence and to give them more opportunities to get practice speaking.
Therefore, the teachers' implementation of scaffolding strategy can be seen in the following explanation.

\subsubsection{Modelling}

Modelling was the first stage for the teacher to stimulate and to prepare the students to get into the new lessons to be learned. The teacher gave students chances to acquaintance and to recognize what to do and how to do the tasks given. In this stage, there are some activities conducted for speaking class. Firstly, the teacher-led the students to think aloud about how native speakers speak. The students were guided by giving some examples, sharing ideas or experiences, and discussing based on the topic. The teacher provided an authentic example as the real performance of speaking from YouTube channel such as international Ted $\mathrm{X}$, the podcast of an international public figure, or watching a short movie. Then, the students were asked to identify or to observe the sources critically and analytically. The teachers guided them by asking some questions related to the materials on the topic of learning. Finally, the students were required to discover the fact based on the examples as their new knowledge. The teacher provided hints to bridge the students to a new lesson by offering some questions such as: 1) what the native speakers were doing? 2) why they were doing so? In the first stage, scaffolding was believed to highlight students' meaning-making process by leading them to a new topic related to some aspects of their prior knowledge (Lambert, [9]). It is crucial for breaking the task into small parts as assisting students to comprehend what is being learned, why and when it is used, and how it is used (Lange, [16]). The teacher may give a detailed explanation or offer some questions to invite students to think critically. Through this strategy, the important information is easily understood by the students. Therefore, the participation of the teachers in assisting students aroused their interests to introduce a new lesson.

\subsubsection{Imitating}

Imitating is aimed to give chance for the students to have experiences based on the authentic sources. The teacher gave time for the class to have practice. Some activities 
had been done in this stage. Firstly, the students were asked to imitate the correct pronunciation of some words. It was found that some students had the wrong pronunciation. Therefore, the teacher had to drill the students to pronounce well by sharing them the authentic audio and offering them the phonetic symbols stated in the dictionary. Secondly, the teacher also stressed the way how to read falling or rising intonation. The students need to take into account as intonation on a sentence or word intonation affects the meaning. Thirdly, the students were asked to work in pairs or groups. All students can ask the teacher for confirmation or clarification if any doubt by offering further explanation.

\subsubsection{Removing}

In this stage, the teacher started to remove the scaffolding. The teacher gave additional extensive instructions. It means the task was getting harder. Based on the classroom observation, each student got a chance to practice by having collaboration with other friends. A collaboration between two students makes them work together to complete one another as a speaker and a speaking reminder. This strategy heightens student engagement in the learning process. In this stage, the teacher walked around to control the class. It provides a good time for the teacher to emphasize or correct understandings of the students related to the task given by giving clarification and confirmation.

\subsubsection{Achieving}

It was time for the students to perform their task. According to Brown and Yule's framework [2], there are three versions of speaking activity: 1). Talk as interaction is an activity to remain students to get used to having a conversation with others. It is an interactive communication which done spontaneously by two or more students. 2). Talk as the transaction is more focus on the message that conveyed and making others person understand what we want to convey, by clearly and accurately. 3). Talk as performance is more focus on monologue better than dialogue such as speeches, public talks, telling story and debate.

The important roles of the teacher in this stage is giving feedback. Feedback is any information that helps the student to improve and to upgrade their speaking ability. It showed that the teacher shared a good verbal prompt by explaining the learner about how to work well, where the knowledge gaps were, and what the next steps that should they do. It means that the teachers were not only correcting the work of the students but the they also gave students little information as to how they can increase their learning or demonstrate more accurately what they have learned.

\subsection{The Effectiveness of Using Scaffolding Strategy in Teaching Speaking}

Based on the observation, some aspects gave a big impact on the effectiveness of using scaffolding strategy in teaching speaking at English course, Kampung Inggris Pare. The teacher gives students a simplified example of a lesson then gradually increased the complexity and difficulty. The example provided students with a concrete example of the learning goals they were expected to achieve. This allowed the students to better focus on the strategy of learning. The teacher also gave them explicit connections between the lesson and the personal interests and experiences of the students as a way to increase understanding or engagement in the learning process.

McKenzie in Diah [7] also investigated some characteristics of effective scaffolding. He mentions that in scaffolding teachers must give clear directions to students about what they are demanded based on the goal of the teaching process. It can follow step by step instructions. These instructions make students keep on the track in processing the tasks. Furthermore, Students entitled to know the aims of the learning. At the end of the learning, assessment, it reflects the expectation of what just mentioned on the learning objectives. The last but not the least, it is important to share authentic sources to reduce stress, time or confusion, and the scaffolding must be able to clarify uncertainty or disappointment. The possibilities for beneficial and exciting learning are unlimited when teachers can provide effective scaffolding that is adjustable, flexible, and dependent on the needs of the children, and when the scaffolding is gradually removed, the children can become independent.

\section{CONCLUSION}

Scaffolding is a kind of teaching strategy that comprehensively view of different facets in the learning process. A good scaffolding means giving more opportunities for learners to have practices. In classroom interaction, teachers should understand the level and the needs of the students. Therefore, they know how to scaffold the students well. For example, if the students work on a series of task, the teachers need to provide them with appropriate support such as giving them clues, maintaining the atmosphere of the class, clarifying uncertainty or ambiguity, and always motivating. The most important thing that teacher should do is providing the learners with authentic resources to give them models of learning. Finally, removing the scaffolding gradually based on the students' learning development is needed. In addition, the teacher should give many opportunities for the students to get practice. It means that the classroom is not dominated by the teachers but the students themselves.

\section{ACKNOWLEDGMENT}

I would like to express my sincere appreciation to my husband, my mom and dad.

\section{REFERENCES}

[1] Abbas, M. 2017. Assessing and Evaluating EFL Learners 'ability in Writing Academic Essay. Proceedings of ISELT FBS Universitas Negeri Padang 5. Padang: FBS UNP Press.

[2] Brown \& G.Yule. 1983. Teaching the Spoken Language: An Approach Based on the Analysis of 
Conversational English. Cambridge: Cambridge University Press

[3] Byrnes, J. P. 2001. Cognitive development and learning in instructional contexts (2nd ed.). Needham Heights, MA: Allyn and Bacon.

[4] Barkelle. 2010. The Roop of Language. California: University of California.

[5] Biswas. (2015). Impact of classroom interaction on English language learning and teaching in secondary level of Bangladesh. Dhaka : Brac University

[6] Chen, M. H. 2016. Theoretical Framework for Integrating Higher-order Thinking into L2 Speaking. Theory and Practice in Language Studies 2(6). 217-226. Accessed from: http://dx.doi.org/10.17507/tpls.0602.01. Retrieved on December 112019.

[7] Diah, A. 2009. Teachers' Scaffolding Talks in Teaching Speaking. Skripsi. Unpublished. Semarang: UNNES

[8] Fisher, D. \& Frey, N. 2008. Better Learning through Structured Teaching: A Framework for the Gradual Release of Responsibility. Virginia: Association for Supervision and Curriculum Development.

[9] Gardner, R., \& Lambert, W. 1959. Motivational variables in second language Acquisition. Canadian Journal of Psychology, 13(4), 266-272. Accessed from: https://eric.ed.gov/?id=ED031968. Retrieved on December 42019.

[10] Gibbons, P. 2002. Scaffolding Language, Scaffolding Learning: Teaching Second Language Learners in the Mainstream Classroom. Portsmouth: Heinemann

[11] Gay, L. R., Mills, G. E., \& Airasian, P. W. 2009. Educational research: Competencies for analysis and applications. Upper Saddle River, New Jersey: Prentice Hall.

[12] Hammond, J. 2001. Scaffolding: A Focus on Teaching and Learning in Literacy Education. Australia: PETA.

[13] Handoyo, P., Februansyah., \& Ashanu. 2020. English Basecamp: An Alternative Learning Method for Enhancing Speaking

Skill (A Case Study in Kampung Inggris, Pare, Kediri, East Java). $\quad$ Retrived rom https://www.researchgate.net/publication/301390858

[14] Harmer, J. 2007. How to Teach English. UK: Pearson Longman.

[15] Heigham, J., \& Juanita. 2009. Qualitative Research in Applied Linguistics. A Practical Introduction. Britain: CPI Antony Rowe, Chippenham and Eastboourne.

[16] Lange, V.L., 2002. Instructional scaffolding: A teaching strategy. $\quad$ Retrieved http://condor.admin.ccny.cuny. edu/ group4/Cano/Cano\%20Paper.doc

[17] Walqu, A. 2006. Scaffolding instruction for English language learners: A conceptual framework. International Journal of Bilingual Education and Bilingualism, 9(2), 159-180. Accessed from: https://doi.org/10.1080/13670050608668639.

[18] Vygotsky, L. S. 1978. Mind in Society: The Development of Higher Psychological Processes. Cambridge. MA: Harvard University Press 